\title{
Mid-Holocene relative sea-level changes along Atlantic Patagonia: New data from Camarones, Chubut, Argentina
}

\author{
Monica Bini, 1,2 Ilaria Isola, ${ }^{2,3}$ Giovanni Zanchetta, ,,2 \\ Marta Pappalardo,' Adriano Ribolini,' Luca Ragaini,' \\ Carlo Baroni, ${ }^{1,3}$ Gabriella Boretto, ${ }^{4}$ Enrique Fuck, ${ }^{5}$ \\ Caterina Morigi,' Maria Cristina Salvatore, 1,3 Davide Bassi,6 \\ Fabio Marzaioli ${ }^{7}$ and Filippo Terrasi ${ }^{7}$
}

\begin{abstract}
This paper concerns the relative sea-level changes associated with the Atlantic Patagonian coast derived from sea-level index points whose elevation was determined by a differential global position system (DGPS). Bioencrustations from outcrops located near Camarones, Chubut, Argentina, consist of autochthonous deposits characterized by Austromegabalanus psittacus (Molina, 1782), encrusting acervulinid foraminifera, coralline red algae and bryozoans. The association of the different organisms is interpreted as being associated with an intertidal environment, and they have been used as index points to establish the relative sea-level position. The main conclusion is that the relative sea-level between c. 7000 and $5300 \mathrm{cal}$. $\mathrm{yr}$ BP was in the range of c. 2-4 m a.s.l., with a mean value of c. $3.5 \mathrm{~m}$ a.s.l. Our data seem to support the existence of different rates of relative sea-level fall in different sectors of Atlantic Patagonia during the Holocene and highlight the importance of a more precise and accurate relative sea-level estimation by producing new data and revisiting the indicative meaning of most of the indicators so far used in the area.
\end{abstract}

\section{Keywords}

Atlantic Patagonia, biological markers, Holocene, relative sea level

Received 22 July 2016; revised manuscript accepted I4 April 2017

\section{Introduction}

The impact of sea-level rise is one of the main concerns related to ongoing global warming, and our capacity to estimate the regional-to-local impact on the coast environment relies on the assumption that many local variables are known (e.g. eustatic sealevel component, tectonic uplift, subsidence and glacial isostatic adjustment; Alley et al., 2005; Blum and Roberts, 2009; Lambeck et al., 2014; Milne et al., 2009; PALeo SEA Level Working Group (PALSEA), 2009). In this framework, the reconstruction of the relative sea-level (RSL) changes at regional scale during the Holocene is particularly relevant and the accuracy of its estimation is crucial for testing geophysical models (Milne and Mitrovica, 2008).

With its $2000 \mathrm{~km}$ of coast, the Atlantic Patagonian passive margin represents a natural link for exploring the RSL evolution between 'near' and 'far' field sites (Milne et al., 2005; Rostami et al., 2000). Therefore, this is a strategic area in which to focus palaeo sea-level studies (Codignotto et al., 1992; Isla and Angulo, 2015; Milne et al., 2005; Pedoja et al., 2011; Ribolini et al., 2011; Rostami et al., 2000; Rutter et al., 1989, 1990; Schellmann and Radtke, 2000, 2003, 2010; Zanchetta et al., 2014). However, a precise and accurate estimation of the RSL in this area has been complicated by several factors, namely (1) precise and accurate sea-level indicators such as notches, inner terrace margins, coral reefs and algal encrustations have been rarely used or not found
(Bini et al., 2013, 2014; Pedoja et al., 2011; Ribolini et al., 2011); (2) sea-level indicators have generally been measured using a barometric altimeter or graduate bars equipped with spirit level, starting from the local high-tide level implying a wide vertical error up to $\pm 3 \mathrm{~m}$ (Zanchetta et al., 2012, 2014); and (3) the coastal area is within the macro-tidal regime (Isla and Bujalesky, 2008) and is characterized by high hydrodynamic regimes, so that most of the sea-level indicators are related to surf and storm extension rather than to mean sea level. As a consequence, Schellmann and

\footnotetext{
'Dipartimento di Scienze della Terra, Pisa University, Italy ${ }^{2}$ Istituto Nazionale di Geofisica e Vulcanologia, Pisa, Roma, Italy ${ }^{3}$ CNR-IGG, Consiglio Nazionale delle Ricerche, Istituto di Geoscienze e Georisorse, Italy

${ }^{4}$ CICTERRA-CONICET Centro de Investigaciones en Ciencias de la Tierra, Universidad Nacional de Córdoba, Argentina ${ }^{5}$ Facultad de Ciencias Naturales y Museo, Universidad Nacional de La Plata, Argentina

${ }^{6}$ Dipartimento di Fisica e Scienze della Terra, Università di Ferrara, Italy ${ }^{7}$ CIRCE, Department of Mathematics and Physics, Second University of Naples, Italy
}

Corresponding author:

Monica Bini, Dipartimento di Scienze della Terra, Via S. Maria 53, 56126 Pisa, Italy.

Email: bini@dst.unipi.it 


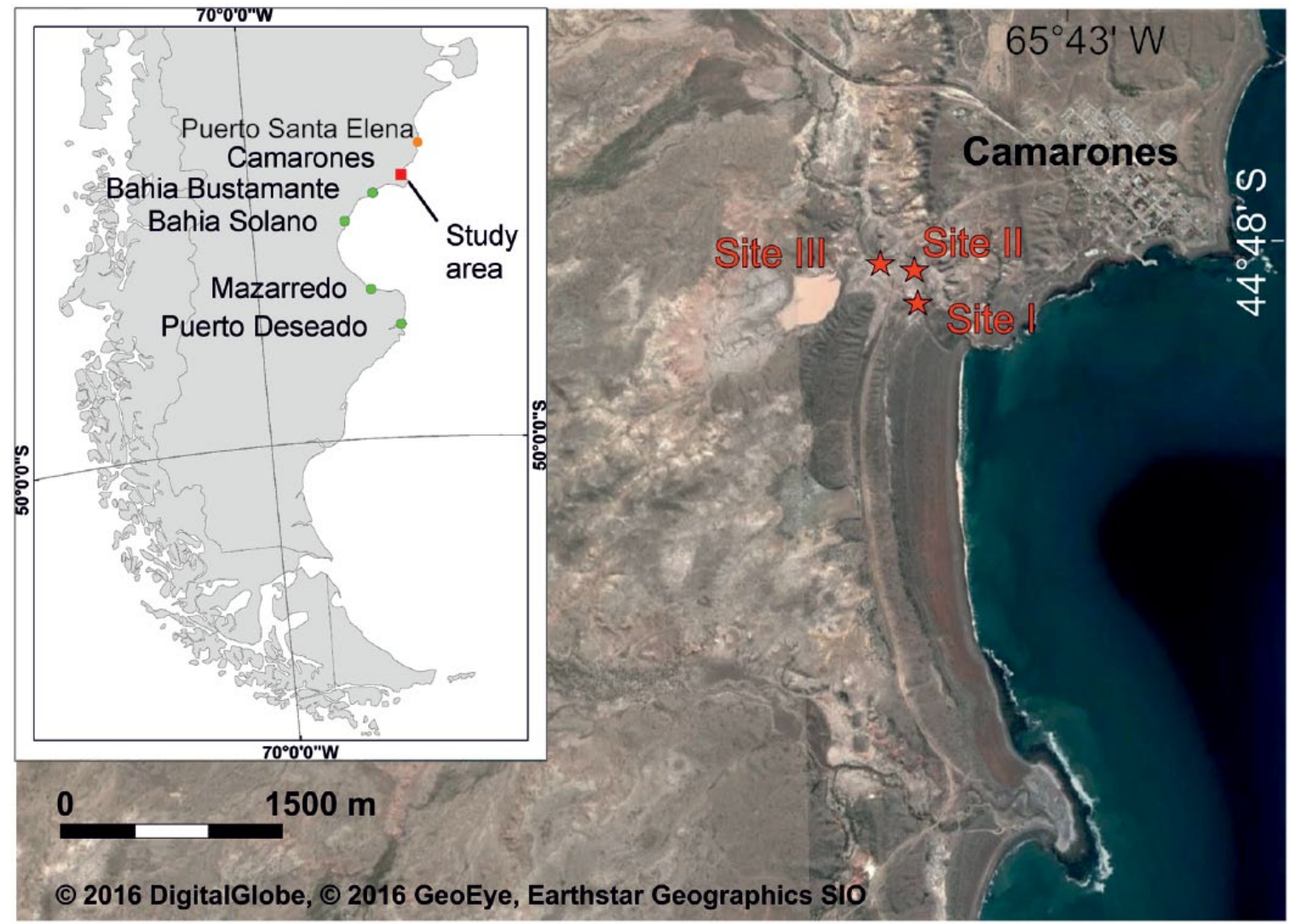

Figure I. Location map of the studied area.

Green circles: sites mentioned along the text; orange circle: location of Puerto Santa Elena; red square: study area; red stars: location of sampled sites.

Radtke (2010) and Zanchetta et al. (2014) reported a different altitudinal estimation for the Holocene RSL, using different indicators related to coastal sediments (i.e. beach ridges and littoral terraces). Some authors take a different approach in measuring reference sea level (e.g. top vs base of beach ridges; Pappalardo et al., 2015), complicating the use of reported data (Codignotto et al., 1992; Pedoja et al., 2011; Ribolini et al., 2011; Rutter et al., 1989, 1990), while others report data related to high-tide level (Schellmann and Radtke, 2010, and references therein, Zanchetta et al., 2012, 2014). The correlation between elevation values measured above high tide and values measured above mean sea level is not so straightforward, and regional correlations are complicated. Although the data from this vast region would be of paramount importance, recent geophysical modelling of sea-level change along the South American coast has not accounted for the Patagonian data (Milne et al., 2005), presumably because of their very high level of uncertainty.

In this paper, we report on a RSL reconstruction based on in situ fossil barnacles and foraminiferal-bryozoan concretions. These sea-level indicators have never been described along the Patagonian coast so far. Here, we describe the indicators found in the territory of Camarones (Chubut, Argentina, Figure 1), one of the nodal areas for the reconstruction of the RSL oscillations along the Patagonian coast owing to its abundance of raised beaches with datable materials (Pappalardo et al., 2015; Schellmann and Radtke, 2010; Zanchetta et al., 2012). Moreover, the elevation of the indicators was for the first time measured by a DGPS, which provided reliable sea-level values at an accuracy never previously reached along the Patagonian coast. Finally, we standardized our data in terms of sea-level index and limiting points (e.g. Rovere et al., 2016; Shennan et al., 2015; Vacchi et al., 2016). This approach, totally new for the Patagonian coast, is mandatory for future regional and extra-regional correlations.

\section{The study area}

The study area is located in the southern part of the Bahía Camarones, Chubut (Argentina), c. 40-km-wide gulf extending from $c$. $44^{\circ} 54^{\prime} \mathrm{S}$ to $44^{\circ} 34^{\prime} \mathrm{S}$ (Figure 1). Structurally, the area is located on the southern edge of the so-called North Patagonia Massif(Feruglio, 1950). Mostly, Jurassic volcanic rocks formed the pre-Quaternary succession (Marifill Formation; Lema et al., 2001). Inland morphology is characterized by flat surfaces covered by Late Neogene-Early Quaternary fluvial gravelly deposits ('rodados Patagonicos' in Martinez and Coronato, 2008), while the landscape is dominated by Quaternary littoral and continental deposits raised at various elevations close to the coast (Lema et al., 2001; Pappalardo et al., 2015).

Like most of coastal Patagonia, the area is dominated by highenergy, macro-tidal and stormy conditions (Isla and Bujalesky, 2008), resulting in a coastal morphology dominated by cliffs, shore platforms and coarse-clastic beach ridges ('swash built ridges' sensu Tanner, 1995).

In Camarones, the predictions of the astronomic tide elevations are calculated in relation to the harbour of Puerto Santa Elena (Figure 1) according to the data released by the Servicio de Hidrografia Naval (http://www.hidro.gov.ar). For the area of Camarones, the maximum tidal range is $c .5 \mathrm{~m}$, while the mean is c. $3.5 \mathrm{~m}$ (Figure 2).

Most of the studies on Holocene coastal evolution are concentrated in the southern part of the Bahía Camarones area and provide a robust chronological constraint for coastal aggradation during the Holocene (Codignotto et al., 1992; Schellmann, 1998; Schellmann and Radtke, 2000, 2003, 2010). In total, two evolutionary phases have been distinguished: (1) the first phase, the maximum Holocene ingression (c. 6.8-6.5 kyr BP), is characterized by the formation of littoral and estuarine deposits (Schellmann and Radtke, 2010) found at the sea embayment along local creeks (locally named 'cañadon'); (2) the successive phase, still 


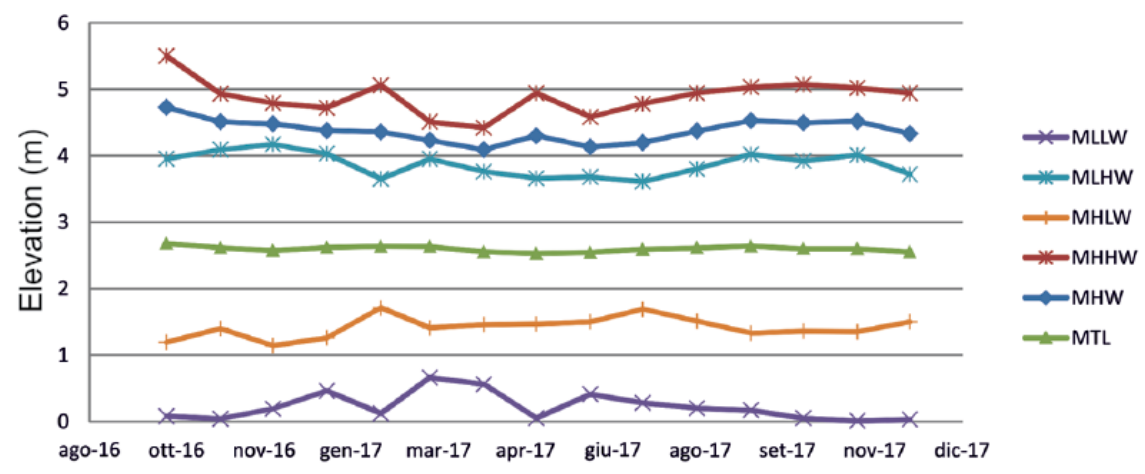

Figure 2. Tide level derived from the current tide tables of Puerto Santa Elena. Elevation data are referred to the reduction plane (theoretical plane located under the mean sea level in order to have only positive tidal values in the tables).

MLLW: mean lower low water; MLHW: mean lower high water; MHLW: mean higher low water; MHHW: mean higher high water; MHW: mean high water; MTL: mean tide level.

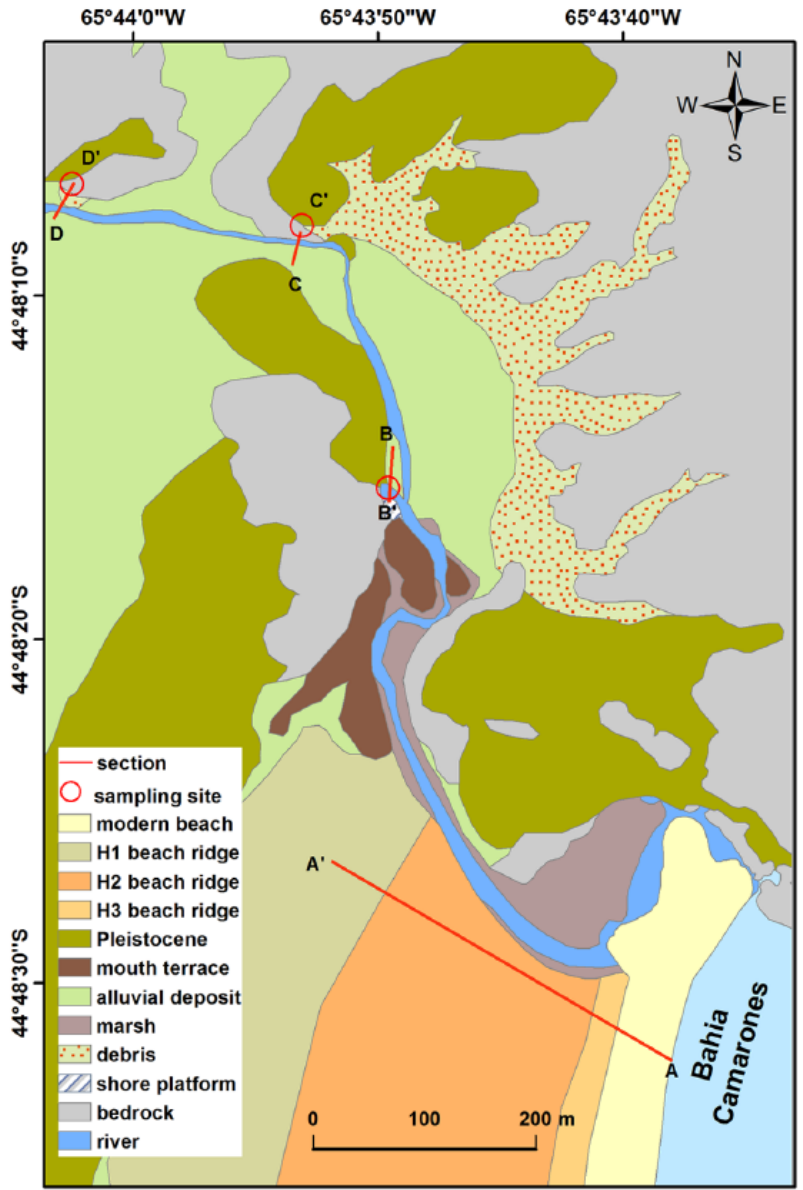

Figure 3. Simplified geomorphological map of the studied area. $\mathrm{H}$ : Holocene beach ridges subdivided into $\mathrm{HI}, \mathrm{H} 2$ and $\mathrm{H} 3$ from the oldest to the youngest beach ridge, according to the morphostratigraphic units identified by Schellmann and Radtke (2010); P: Pleistocene beach ridge.

active, is marked by discontinuous coastal aggradation, with the formation of prominent higher gravelly beach ridges parallel to the present-day coast (Figure 3).

\section{Methodology}

For stratigraphic and geomorphological investigations, we followed the same approach already used in previous studies conducted in the area (Isola et al., 2011; Ribolini et al., 2011). A preliminary remote sensing analysis was performed using LANDSAT 7 images (acquisition dates, 1999-2001) and Quick Bird images (acquisition date, 2004) supported by the digital elevation model Shuttle Radar Topography Mission (SRTM; https://www. jpl.nasa.gov/srtm). After this preliminary phase, field surveys were carried out in February 2009, 2010 and 2011 (Pappalardo et al., 2015; Zanchetta et al., 2012). In the first phase, the elevation data were obtained using graduate bars equipped with spirit level, starting the measurements from the nearest Instituto Geográfico Nacional point (IGN), with a precision in the order of $\pm 0.3 \mathrm{~m}$ (Zanchetta et al., 2014). A field survey conducted in January 2016 was dedicated to the DGPS measurement of sea-level indicators. The data were acquired by the WGS 84 Geographic Coordinate System (maximum error in elevation of acquired points was $10 \mathrm{~cm}$ ) and post-processed and referred to the current global geoid model EGM2008 (Pavlis et al., 2012; 4 cm planimetric error and $9 \mathrm{~cm}$ elevation error). Elevation measurements indicated as 'a.s.l.' in this paper are referred to the vertical datum EGM2008. These data integrate and basically confirm those previously obtained by graduated bar measurement. For the study area, Schellmann and Radtke (2010) reported the altitudinal measurement of different sea-level indicators, using a barometric altimeter (reported precision $\pm 1 \mathrm{~m}$ ) daily calibrated with the tide level. In order to compare our data with those reported by Schellmann and Radtke (2010), we used the DGPS to re-measure some of the sections described by Schellmann and Radtke (2010).

In situ barnacles and encrusting foraminiferal deposits were collected in the field and measured with DGPS (Figures 1 and 3), alongside additional samples with articulated valves of Mytilus edulis from littoral deposits. The samples for radiocarbon dating were cleaned in an ultrasonic bath with the addition of oxygen peroxide and then gently etched with diluted $\mathrm{HCl}$ to remove any recent carbonate encrustation. Radiocarbon measurement was carried out at the CIRCE laboratory of Caserta, Italy (Terrasi et al., 2007, 2008) and calibrated using the Marine13 curve (Reimer et al., 2015). However, the reservoir effect values for the Southern Atlantic Ocean and, in particular, Patagonia, are not well constrained (Schellmann and Radtke, 2010). Specific studies suggest that for different localities of the Patagonian coast between $c .42^{\circ} \mathrm{S}$ and $50^{\circ} \mathrm{S}$, the reservoir effect can vary between 180 and 530 years (Butzin et al., 2005; Cordero et al., 2003; Schellmann and Radtke, 2010).

Collected species, radiocarbon dates and sampling site elevation are reported in Table 1. The state of preservation of barnacles and encrustations, prior to dating were assessed by stereomicroscope analysis of thin sections and was investigated by $x$-ray power diffraction (XRD).

\section{Results}

The study area is located along a small river to the south of the Camarones village (Figure 1). A succession of 
Table I. Radiocarbon ages obtained for this study were performed using IntCall 3 and Marine 3 radiocarbon age calibration curves (Reimer et al., 2015).

\begin{tabular}{lllll}
\hline Laboratory code & Sample code & ${ }^{14} \mathrm{C}$ yr BP & Cal. yr BP $( \pm 2 \sigma)$ & Material \\
\hline DSH2744 & Wpi-424-2 & $5641 \pm 46$ & $5924-6168$ & Australomegabalanus psittacus \\
DSH3170 & Wpi-436A & $5515 \pm 50$ & $5741-6015$ & Australomegabalanus. psittacus \\
DSH2738 & AO-164 & $5132 \pm 67$ & $5313-5608$ & Australomegabalanus psittacus \\
DSH2742 & Wpi-436b & $4995 \pm 89$ & $5106-5560$ & Encrustation \\
DSH2736 & AO-154D & $5567 \pm 44$ & $5865-6099$ & Mytilus. edulis \\
DSH2745 & Wpi-436 & $5562 \pm 43$ & $5861-6092$ & Mytilus edulis \\
DSH4023 & AO-164 & $5370 \pm 60$ & $5604-5878$ & Mytilus edulis \\
Hd-23504 & Pa04/7a & $5560 \pm 38$ & $5866-6065$ & Protothaca antiqua \\
\hline
\end{tabular}

aData from Schellmann and Radtke (2010).
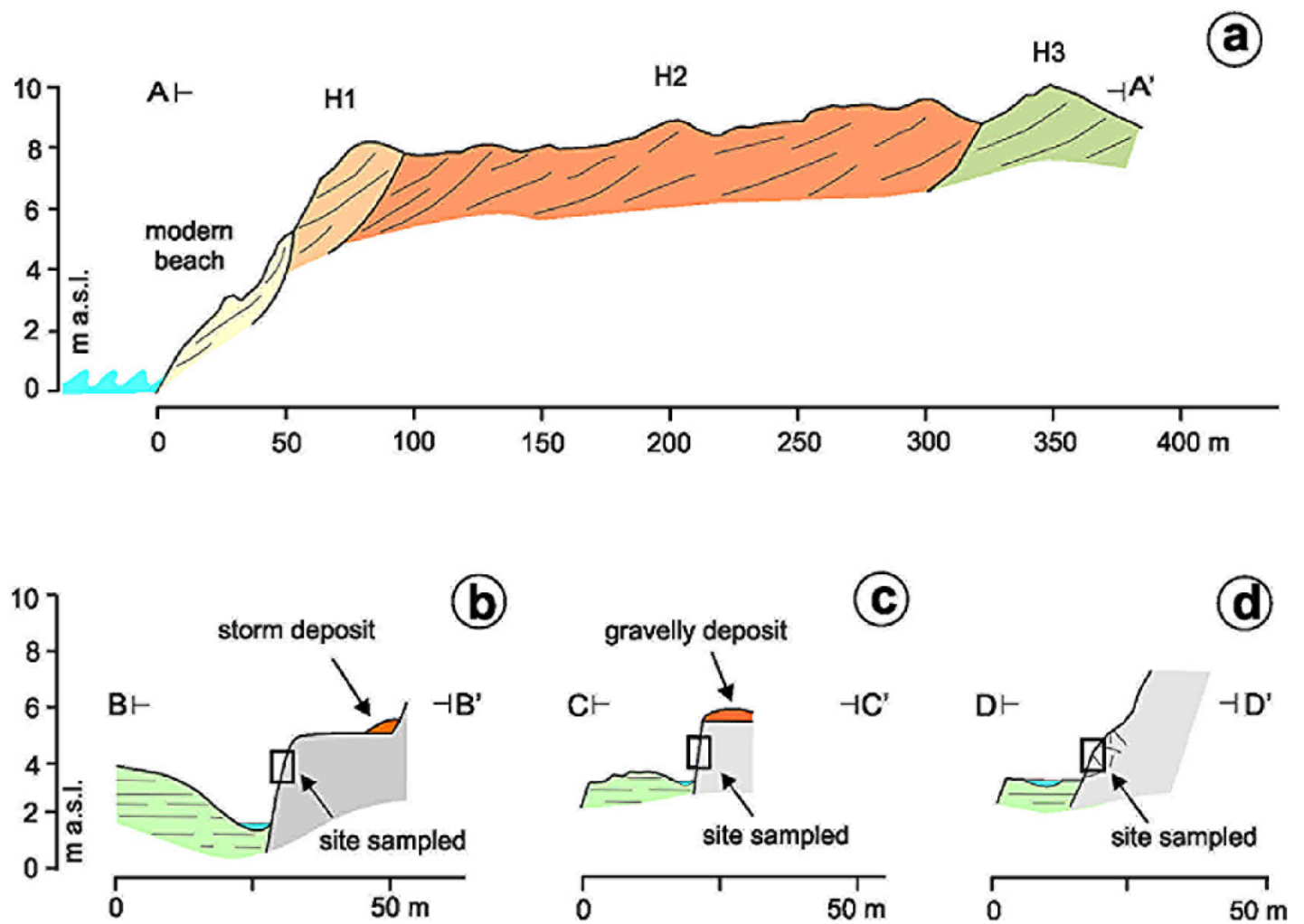

Figure 4. Geological sections (see map in Figure 2 for location): (a) geological section $\mathrm{AA}^{\prime}$, (b) geological section BB', (c) geological section $\mathrm{CC}^{\prime}$ and (d) geological section $\mathrm{DD}^{\prime}$.

Holocene-Pleistocene gravelly beach ridges forms the coastal strandplain, up to a distance of $>500 \mathrm{~m}$ inland from the present coastline. This arched beach ridge system is incised by a river valley where alluvial, marsh and coastal sediments were deposited (Figures 3 and $4 \mathrm{a}$ ). Along the river valley, bedrock crops out forming steep cliffs in some places and relict shore platforms locally. In total, three rocky outcrops, composed by welded ignimbrites of Marifil Formation, yielded barnacles (A. psittacus; Molina, 1782) and foraminiferal encrustations (mostly Acervulina inhaerens; Schulthe, 1854) in life position (Figures 3, $4 b-d, 5$ and 6). The first outcrop (Figures 3 and $4 \mathrm{~b}$ ) is formed by a vertical cliff exposed for c. 3-4 $\mathrm{m}$ and a flat top surface, located at c. $5 \mathrm{~m}$ a.s.l., representing the remnant of a shore platform. Barnacles and foraminiferal encrustations are located on the cliff where barnacles are discontinuously spread for $<1 \mathrm{~m}$ (between 3.4 and $3.8 \mathrm{~m}$ a.s.1.) and encrustations for $c .1 .5 \mathrm{~m}$ (between 3.3 and $4.8 \mathrm{~m}$ a.s.l.; Figures $4 \mathrm{~b}$ and 5). The second outcrop (Figures 3, 4c and 5) is formed similarly by a vertical cliff with an on-top shore platform covered by gravelly deposits. On the vertical cliff barnacles span between 3.1 and $3.9 \mathrm{~m}$ a.s.l. and incrustations from 3.3 to $4.6 \mathrm{~m}$ a.s.l. The third sampled inland site is represented by boulders at the toe of a rocky cliff (Figures 3, 4d and 5). Barnacles and incrustations, spanning in elevation between 3.2 and $4.2 \mathrm{~m}$ a.s.l., developed on the blocks and at the base of the cliff.

In each sampled site, barnacles (A. psittacus) occur as isolated or two to three jointed individuals (Figure 6). Most of the encrustations consist of foraminifera identifiable as Acervulina inhaerens (Figure 6d-f), which is the dominant component, while arborescent forms such as Homotrema and Miniacina are less frequent. All these encrusting foraminifera form repetitive or randomly arranged inner superimposed growth stages. Superimposed growth stage bryozoans and rare coralline red algal thalli occur within the $A$. inhaerens. The bryozoans are represented by encrusting cheilostomes (Anascina?), and the very low preservation does not allow their systematic identification. The corallines are almost micritized and/or recrystallized. A possible uniporate conceptacle was also identified. This reproductive character along with the vegetative characters (cell fusions and monomerous cell filaments) suggests a possible ascription to the Mastophoroideae subfamily (Figure 6d-f). 
The top surface of the first outcrops is carved in a previously modelled rocky terrace attributed by Schellmann and Radtke (2010) to marine isotope stage 7 (MIS 7). A shell accumulation of M. edulis rests directly on the lateral margin of the lower shore platform, sealed by a few decimetre-thick slope deposits. No other deposits cover the shore platform. This shell accumulation, with a poor sandy matrix of some millimetre-size rounded clasts, and some shells with valves still joined, is consistent with a storm deposit. One shell from the accumulation yielded a radiocarbon age of $5562 \pm 43 \mathrm{yr}$ BP. Concretion from the vertical cliff of this

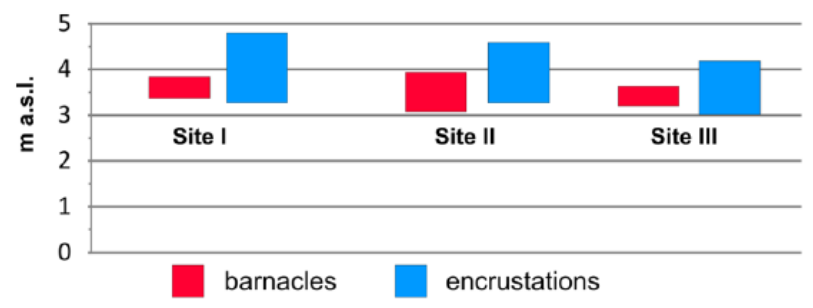

Figure 5. Elevation range of barnacles and incrustations in the three outcrops described. The data were measured by DGPS Trimble with a maximum error of $10 \mathrm{~cm}$ in elevation. outcrop yielded a radiocarbon age of $4995 \pm 89 \mathrm{yr}$ BP, whereas one barnacle yielded $5515 \pm 50 \mathrm{yr}$ BP.

The top surface of the second rocky outcrop is covered by gravelly deposits, which did not yield suitable material for dating (i.e. only fragmented shells and not entire shells with articulated valves). However, these deposits are reasonably related to the formation of the Holocene erosional platform. In the vertical cliff of this second outcrop, a barnacle yielded a radiocarbon age of $5132 \pm 67 \mathrm{yr}$ BP. Here, the rocky cliff was crossed by some vertical fissures containing sediment and some fossil remains, including M. edulis and barnacles (Figure 6c). One sample with articulated valves of $M$. edulis collected from the infilling of the vertical fissures yielded a radiocarbon age of $5567 \pm 44 \mathrm{yr}$ BP. On the third site, a sample of barnacles revealed a radiocarbon age of $5641 \pm 46 \mathrm{yr}$ BP.

All the rocky cliffs are partially sealed by gravelly estuarine terraced deposits, namely, valley-mouth terraces, according to Schellman and Radtke (2010, Figure 3). These deposits contain shells (principally Prothotaca antiqua and M. edulis) accumulated in lenses for which Schellman and Radtke (2010) reported a radiocarbon age of $5560 \pm 38 \mathrm{yr}$ BP. A new radiocarbon measurement was undertaken on an M. edulis from the same deposits, directly sealing the second cliff, yielding a consistent age of $5370 \pm 60 \mathrm{yr}$ BP.
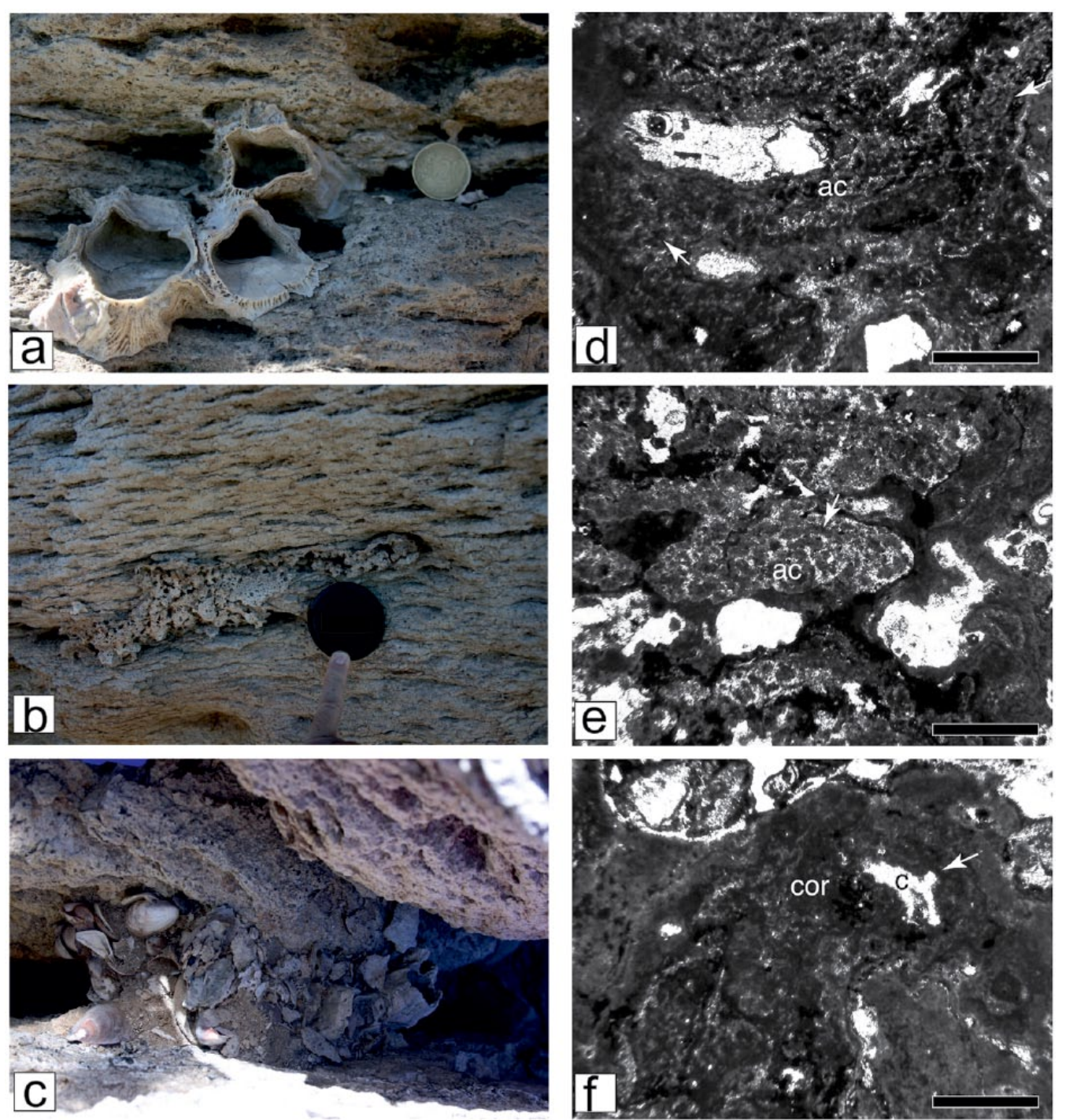

Figure 6. Images of (a) barnacles (Austromegabalanus psittacus), (b) incrustation, and (c) storm deposit infilling fractures within bedrock. Thin-section microscope photographs of the studied bioencrustations. (d, e) Encrusting acervulind shells (ac) showing chamber arrangement (arrows) with successive layers in sub-axial sections; the chambers are open in lateral walls (arrows); (f) encrusting coralline algal thallus (cor) showing the transversal section of a uniporate conceptacle (c) with a cylindrical porecanal (arrow). Scale bar represents $500 \mu \mathrm{m}$. 


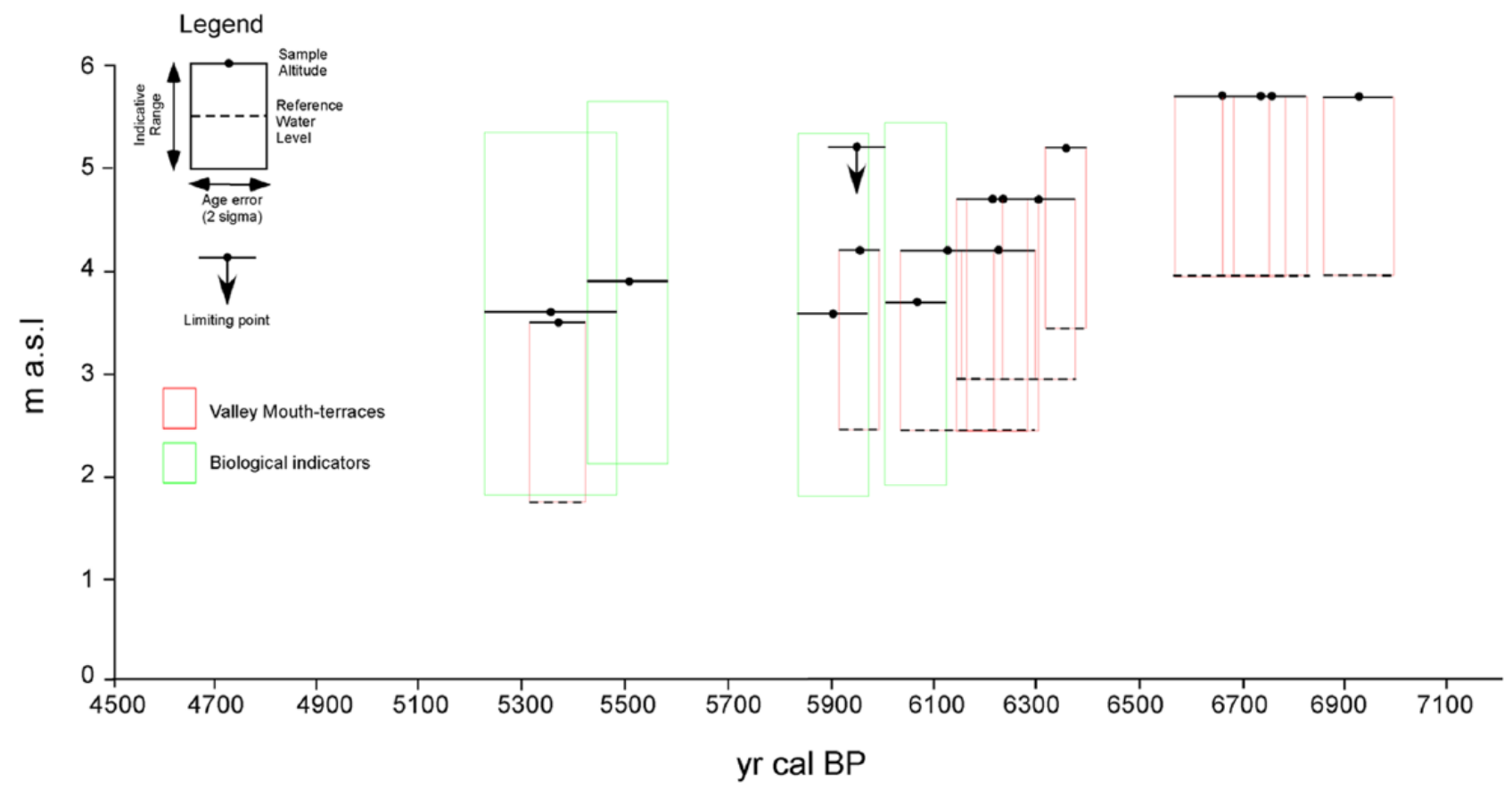

Figure 7. Total plot of the Camarones area index points: fixed biological indicators from this work; valley-mouth terrace indicators from Schellmann and Radtke (2010). Limiting point from this work.

\section{Discussion}

Sea-level indicators in Atlantic Patagonia have yielded controversial results in the estimation of past RSL, and their accuracy and precision have been poorly defined, both for the precision of the measurement of the method applied (barometric altimeter, local maps and graduate bars) and for the unclear meaning of the indicators, for example, storm and maximum high tide (Codignotto et al., 1992). Therefore, it is mandatory to transform sea-level indicators into index or limiting points to improve RSL estimations (Shennan et al., 2015). So far, the most precise and accurate indicators described for Atlantic Patagonia, which can be easily transformed into sea-level index points, are the erosive notches. Specifically, the retreat point of notch defines the main high-tide values ( $\pm 0.3 \mathrm{~m}$; Bini et al., 2014).

The Camarones association of barnacles, bryozoans and encrusting foraminifera can be generically interpreted as intertidal-subtidal indicator (e.g. Baker et al., 2001; Ferranti et al., 2006; Laborel and Laborel-Deguen, 1994; Pirazzoli et al., 1985; Rovere et al., 2015, 2016).

Specifically, the collected samples of barnacle correspond to the 'acorn barnacle' A. psittacus (Figure 6a), a species inhabiting mainly rocky substrates of the subtidal zone, where it forms dense aggregates between 5 and $7 \mathrm{~m}$ in water depth (López et al., 2010). However, the functional faculties of the barnacle could account for the high capacity of $A$. psittacus to also colonize habitats exposed to prolonged emersion periods like those characterizing intertidal settings (López et al., 2003). The barnacles generally live in groups forming dense hummocks but in less favourable locations like the intertidal zones where they are less frequent and distant from each other. The relatively sparse association of barnacles in our sampling sites indicates the upper limit of the living range.

Present-day acervulinid foraminifera show a large bathymetric range from the intertidal zone down to $100 \mathrm{~m}$ in water depth (Bassi et al., 2012; Perry and Hepburn, 2008). Although acervulinids are more common in deeper water settings where interspecific competition for space may be reduced (Rasser and Piller, 1997), Acervulina inharens thrives in shallow water Bahamas shelf settings ( $<30 \mathrm{~m}$; Walker et al., 2011). Homotrema is reported from high-energy shallow water settings (Gischler and Möder, 2009). So far, Homotrema has seemed to be an excellent indicator of high-energy water conditions for shallow near-shore and shelf/ edge habitats, where water energy during tidal exchange is greater in tropical and subtropical environments (Walker et al., 2011), and even in this case, it is consistent with the intertidal zone. Moreover, it is generally assumed that fossil barnacles and bioencrustation in growth positions are easily eroded (Pirazzoli et al., 1985). Therefore, the survival of encrusted shell remains at higher-than-present levels suggests a sea-level fall sufficiently rapid for the shell to escape obliteration by wave erosion (Pirazzoli et al., 1985), a condition favouring the preservation of species that live in the upper limit of the high tide. In most cases, the age of the outer shells on a thick vertical encrustation will correspond to the terminal period of the former sea-level stand (Baker et al., 2001). Therefore, the Camarones barnacles, bryozoans and encrusting foraminifera association can be considered substantially intertidal, and its definition of index point could be possible on the basis of tide oscillations (Shennan et al., 2015; Vacchi et al., 2016). By assuming that our association is strictly intertidal between $c .6100$ and c. $5300 \mathrm{cal}$. yr BP RSL was around 3.7 and $3.9 \mathrm{~m}$ a.s.l. (Figure 7).

For the studied area, Schellmann and Radtke (2010) reported several radiocarbon measurements for different sea-level indicators, which can complete and improve the interpretation of the data discussed in this paper. In our study, we selected only the valley-mouth terrace sea-level indicators, which are less affected by storm deposition, compared with beach ridges, thus reducing the errors in elevation estimation (Schellmann and Radtke, 2010; Tamura, 2012; Zanchetta et al., 2014). According to the observations of modern analogs by Schellmann and Radtke (2010), valley-mouth terraces are estuarine deposits that contain lateral/ vertical interfingering of mollusc-bearing littoral sediments and fluvial deposits forming at the mouth of small local rivers. The top of the valley-mouth terraces correlates directly to the former elevation of the high-tide level representing a suitable indicator to be used as index point. As can be inferred from Figure 7, RSL from mouth terraces is consistent within the indicative meaning of barnacles and encrustations supporting our interpretation. 
Indeed, at least three of our biological indicators, chronologically overlapping the data from valley-mouth terraces, lie within $1 \mathrm{~m}$ of the top of the mouth terraces. Significantly, the presence of the storm deposit dated c. 5950 cal. yr BP, located directly on the erosive shore platform on top of the first cliff, represents an upper RSL limiting point (Figure 7), constraining fairly well the values of fossil barnacles and mouth terrace. The storm deposit can also be considered a termine ante quem for the formation of the rock platform on top of the first outcrop.

Considering the elevation of the index points obtained from mouth terraces in the area together with the biological indicators discussed in this paper, this evidence collectively (Figure 7) agrees on indicating the RSL to be from $c .2$ to $c .4 \mathrm{~m}$ a.s.1. between $c .5300$ and 7000 cal. yr BP.

In Figure 7, the altimetric and chronological data of the valleymouth terraces show a highstand between $c .7000$ and $6600 \mathrm{cal}$. yr BP at $c .4 \mathrm{~m}$ a.s.l., followed by a progressive fall to $c .2-2.5 \mathrm{~m}$ between 6200 and 5300 cal. yr BP. The radiocarbon age of the storm deposit above the shore platform may indicate that this shore platform was related to the higher sea stand at $c .7000 \mathrm{cal}$. yr BP and was no longer significantly active during the progressive fall after $c$. 6200 cal. yr BP, only occasionally reached by storms. However, the RSL variation recorded by the valley-mouth terraces is not shown by barnacles and encrustation, thus suggesting that most of this variation falls within the range of error of the two index points.

Following Shennan and Horton (2002), the total vertical error (including vertical distribution of encrustation and barnacles, Figure 5; measurement errors and indicative meaning) for the biological sea-level indicators is c. $3.8 \mathrm{~m}$. According to Schellman and Radtke (2010), a minimum vertical error for valley-mouth terraces can be calculated at c. $2 \mathrm{~m}$. However, a precise estimation of error should be associated with an accurate review of modern analogs on the valley-mouth terraces and of other findings from fixed biological indicators. Overall, the mean RSL between $c$. 7000 and 5300 cal. yr BP, which can be obtained considering all the index points, is $3.4 \pm 0.6 \mathrm{~m}$ a.s. 1 .

Initial glacio-hydro-isostatic models of the Patagonian coast suggested that the shoreline could be characterized by currently raised beaches, which started to form as soon as ice-sheet melting ceased (Clark et al., 1978). A more recent model (Milne and Mitrovica, 2008) predicted that RSLs might have exceeded present by $c$. $5 \mathrm{~m}$ at $6000 \mathrm{cal}$. yr BP. Field evidence indicates that the highstand is somewhat $c .1 .5 \mathrm{~m}$ lower than model prediction. These ranges of measurement can agree with the model considering all the vertical errors associated with the index points discussed.

A comparison of the different sectors of the Atlantic Patagonian coast is complicated by many factors. Codignotto et al. (1992) found a significant rate of RSL changes during the Holocene in relation to different tectonic sectors. They indicated a maximum highstand at $c .12 \mathrm{~m}$ a.s.l. for the period c. 4-8 kyr BP for the area of Camarones-Bustamante, at c. $2 \mathrm{~m}$ a.s.l. for the period c. 4-6 kyr BP in the area of Bahia Solano (Figure 8). These data are affected by poor quality radiocarbon dating together with low altimetric accuracy. Moreover, most data are obtained by measuring the altitudinal crest of beach ridges, which are largely affected by storm conditions (Schellmann and Radtke, 2010; Tamura, 2012; Zanchetta et al., 2014). On the contrary, Schellmann and Radtke (2010) observed no appreciable differences along the Patagonia coast. However, using different sea-level indicators, the authors observed different values (reported above high tide (a.h.T)) for the highstand, occurring between c. 6 and 7 cal. kyr BP, ranging from c. 9 to $5 \mathrm{~m}$ a.h.T. Bini et al. $(2013,2014)$ and Zanchetta et al. (2014) reported an RSL at $c .8 \mathrm{~m}$ a.s.l. at $c$. 3500 cal. yr BP by accurate measurements of erosive notches in the Puerto Deseado area (Figure 1). Owing to the difficulty in dating erosive notches, Zanchetta et al. (2014) suggested that these

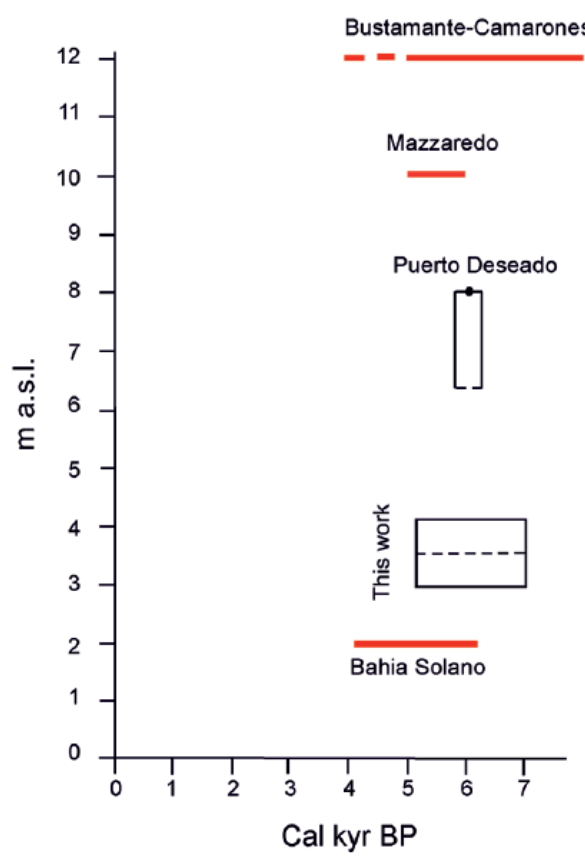

Figure 8. Relative sea-level (RSL) data along the Patagonian coast for the 'highstand' by different authors: redline: data from Codignotto et al. (1992); dark line: data from Zanchetta et al. (2014) and from this work reported as a.s.l. (for sites location, see Figure I). The indicative meaning reported in this figure is discussed in the text, while the indicative meaning cannot be reported for Codignotto et al. (1992).

notches were formed during a previous Holocene highstand. In any case, the RSL marked by well-preserved notches is higher than that observed in the Camarones area, indicating that a different RSL may exist along the Patagonian coast during the same period (Figure 8).

In this respect, Pedoja et al. (2011) suggested that the presence of the Nazca and the Antarctic plates subducting under South America and southern Patagonian, respectively (Ramos and Ghiglione, 2008, and references therein), may have produced a long wavelength tectonic effect, onto which the glacio-hydro-isostatic signal is overprinted. This signal can vary according to the different sectors of the Atlantic Patagonian coast. More recently, Isla and Angulo (2015) in an accurate review of existing data from MIS5 terraces along Atlantic Patagonia have shown the importance of the effect of subduing plates in determining regional trends in the rate of uplift. The data discussed in our paper seem to support the possible existence of a different uplift rate over the Atlantic Patagonian coast. However, subtle differences can only be identified by appropriate markers and are probably difficult to identify using the data so far available, which are affected by large measurement uncertainty and incomplete understanding of the indicator meaning.

\section{Conclusion}

We have presented the first accurate middle-Holocene RSL determination for a well-dated period of time using different sea-level indicators, for the Atlantic Patagonian coast, with altitudinal measurement obtained using DGPS. Once dated, and their meaning and vertical error discussed, the indicators were transformed into index points. In this paper, using the available evidences, we suggest that the in situ association of sparse barnacles, bryozoans and encrusting foraminifera can have the indicative meaning of intertidal indicators, in the absence of modern analogs for the area. The mean RSL was estimated at $c .3 .50 \mathrm{~m}$ a.s.l., lower than the $c$. $5 \mathrm{~m}$ predicted by the global model, using estuarine deposits (i.e. 
mouth terraces) together with barnacles, bryozoans and encrusting foraminifera, for the period comprised between c. 5300 and 7000 cal. yr BP (Milne and Mitrovica, 2008).

Regional considerations indicating that the existence of different rates of RSL falls in different sectors of Atlantic Patagonia, as reported in the past by Codignotto et al. (1992) and refuted by recent works (Schellmann and Radtke, 2010), need to be reconsidered. In this framework, the existence of general tectonic components of uplift due to the subduction of the Nazca and the Antarctic plates (Isla and Angulo, 2015; Pedoja et al., 2011) needs to be better clarified. Indeed, it is necessary to identify the sectors characterized by different rates of uplift, using a multi-indicator approach and by searching further sea-level indicators, different from those traditionally used in this area (Zanchetta et al., 2014). In this regard, it is fundamental to transform these indicators to sea-level index points and to clarify the indicative meaning also of the previous indicators studied for more correct regional correlations. This is particularly important for such a vast area, for which good quality data are still sparse. An improvement in the quality of the indicators is a priority for future research.

\section{Acknowledgements}

We thank J. Cause and the non-profit organization CADACE for the logistical support in the field campaign. We are strongly indebted to two anonymous reviewers for their insightful criticism and encouraging suggestions that improved the manuscript.

\section{Funding}

This work was funded by the University of Pisa (Progetto Ateneo 2007, Leader G. Zanchetta, Progetto Ateneo 2014, Leader G. Zanchetta) and MIUR (PRIN2008, Leader G. Zanchetta).

\section{References}

Alley RB, Clark PU, Huybrechts P et al. (2005) Ice-Sheet and sea-level changes. Science 310: 456-460.

Baker RGV, Haworth RJ and Flood PG (2001) Warmer or cooler late Holocene marine palaeoenvironments? Interpreting southeast Australian and Brazilian sea-level changes using fixed biological indicators and their $\delta^{18} \mathrm{O}$ composition. Palaeogeography, Palaeoclimatology, Palaeoecology 168: 249272.

Bassi D, Iryu Y, Humblet M et al. (2012) Recent macroids on the Kikai-jima shelf, Central Ryukyu Islands, Japan. Sedimentology 59: 2024-2041.

Bini M, Consoloni I, Isola I et al. (2013) Markers of palaeo sealevel in rocky coasts of Patagonia (Argentina). Rendiconti Online Societa Geologica Italiana 28: 24-27.

Bini M, Isola I, Pappalardo M et al. (2014) Abrasive notches along the Atlantic Patagonian coast and their potential use as sea level markers: The case of Puerto Deseado (Santa Cruz, Argentina). Earth Surface Processes and Landforms 39: $1550-1558$

Blum MD and Roberts HH (2009) Drowning of the Mississippi Delta due to insufficient sediment supply and global sea-level rise. Nature Geoscience 2: 488-491.

Butzin M, Prange B and Lohmann MG (2005) Radiocarbon simulations for the glacial ocean: The effects of wind stress, Southern Ocean sea ice and Heinrich events. Earth and Planetary Science Letters 235: 45-61.

Clark JA, Farrell WF and Peltier WR (1978) Global changes in postglacial sea level: A numerical calculation. Quaternary Research 9: 265-287.

Codignotto JO, Kokot RR and Marcomini SC (1992) Neotectonism and sea level changes in the coastal zone of Argentina. Journal of Coastal Research 8: 125-133.
Cordero RR, Panarello H, Lanellotti S et al. (2003) Radiocarbon age offsets between living organisms from the marine and continental reservoir in coastal localities of Patagonia. Radiocarbon 45: 9-15.

Ferranti L, Antonioli F, Mauz B et al. (2006) Markers of the last interglacial sea-level high stand along the coast of Italy: Tectonic implications. Quaternary International 145: 30-54.

Feruglio E (1950) Descripción geológica de la Patagonia (Dirección General de Y.P.F., Tomo 3). Buenos Aires: Impr. y Casa Editora 'Coni', pp. 74-197.

Gischler E and Möder A (2009) Modern benthic foraminifera on Banco Chinchorro, Quintana Roo, Mexico. Facies 55: 27-35.

Isla FI and Angulo RJ (2015) Tectonic processes along the South America coastline derived from quaternary marine terraces. Journal of Coastal Research. Epub ahead of print 22 April. DOI: 10.2112/JCOASTRES-D-14-00178.1.

Isla FI and Bujalesky GG (2008) Coastal geology and morphology of Patagonia and the Fuegian Archipelago. In: Rabassa J (ed.) The Late Cenozoic of Patagonia and Tierra Del Fuego (Developments in quaternary science, vol. 11). London: Elsevier, pp. 227-240.

Isola I, Bini M, Ribolini A et al. (2011) Geomorphologic map of Northeastern sector of San Jorge Gulf (Chubut, Argentina). Journal of Maps 7: 476-485.

Laborel J and Laborel-Deguen F (1994) Biological indicators of relative sea-level variations and of co-seismic displacements in the Mediterranean region. Journal of Coastal Research 10: 395-415.

Lambeck K, Rouby H, Purcell A et al. (2014) Sea level and global ice volumes from the last glacial maximum to the Holocene. Proceedings of the National Academy of Sciences of the United States of America 111: 15296-15303.

Lema H, Busteros A and Franchi M (2001) Hoja Geológica 4566II y IV, Camarones (1:250.000). Programa Nacional de Cartas Geológicas de la República Argentina. Boletin No. 261. Buenos Aires: Servicio Geologico Minero Argentino, p. 53.

López DA, Castro JM, González ML et al. (2003) Physiological responses to hypoxia and anoxia in the giant barnacle, Austromegabalanus psittacus (Molina, 1782). Crustaceana 76: 533-545.

López DA, Lopez BA, Pham CK et al. (2010) Barnacle culture: Background, potential and challenger. Aquaculture Research 41: 367-375.

Martinez OA and Coronato AMJ (2008) The Late Cenozoic fluvial deposits of Argentine Patagonia. In: Rabassa J (ed.) The Late Cenozoic of Patagonia and Tierra Del Fuego (Developments in quaternary science, vol. 11). London: Elsevier, pp. 205-226.

Milne GA and Mitrovica JX (2008) Searching for ecstasy in deglacial sea-level histories. Quaternary Science Reviews 27: 2292-2302.

Milne GA, Long AJ and Bassett SE (2005) Modelling Holocene relative sea-level observations from the Caribbean and South America. Quaternary Science Reviews 24: 1183-1202.

Milne GA, Gehrels WR, Hughes CW et al. (2009) Identifying the causes of sea-level change. Nature Geoscience 2: 471-478.

PALeo SEA Level Working Group (PALSEA) (2009) The sealevel conundrum: Case studies from palaeo-archives. Journal of Quaternary Science 25: 19-25.

Pappalardo M, Aguirre M, Bini M et al. (2015) Coastal landscape evolution and sea-level change: A case study from Central Patagonia (Argentina). Zeitschrift für Geomorphologie 52: 145-172.

Pavlis NK, Holmes SA, Kenyon SC et al. (2012) The development and the evaluation of the Earth gravitational model 2008 (EGM2008). Journal of Geophysical Research: Solid Earth 117: B04406. 
Pedoja K, Regard V, Husson L et al. (2011) Uplift of quaternary shorelines in eastern Patagonia: Darwin revisited. Geomorphology 127: 121-142.

Perry CT and Hepburn LJ (2008) Syn-depositional alteration of coral reef framework through bioerosion, encrustation and cementation: Taphonomic signatures of reef accretion and reef depositional events. Earth-Science Reviews 86: 106-144.

Pirazzoli PA, Delibrias G, Kawana T et al. (1985) The use of Barnacles to measure and date relative sea-level changes in the Ryukyu Island, Japan. Palaeogeography, Palaeoclimatology, Palaeoecology 49: 161-174.

Ramos VA and Ghiglione MC (2008) Tectonic evolution of the Patagonian Andes. In: Rabassa J (ed.) The Late Cenozoic of Patagonia and Tierra Del Fuego (Developments in quaternary science, vol. 11). London: Elsevier, pp. $57-71$.

Rasser M and Piller WE (1997) Depth distribution of calcareous encrusting associations in the northern Red Sea and their geological implications. In: Lessios HA and Macintyre IG (eds) Proceedings of the 8th International Coral Reef Symposium, vol. 1. Balboa: Smithsonian Tropical Research Institute, pp. 743-748.

Reimer PJ, Bard E, Bayliss A et al. (2015) IntCal13 and Marine13 radiocarbon age calibration curves $0-50000$ years cal BP. Radiocarbon 55(4): 1869-1887.

Ribolini A, Aguirre M, Baneschi I et al. (2011) Holocene beach ridges and coastal evolution in the Cabo Raso Bay (Atlantic Patagonian Coast, Argentina). Journal of Coastal Research 27: 973-983.

Rostami K, Peltier WR and Mangini A (2000) Quaternary marine terraces, sea-level changes and uplift history of Patagonia, Argentina: Comparisons with predictions of the ICE-4G (VM2) model of the global process of glacial isostatic adjustment. Quaternary Science Reviews 19: 1495-1525.

Rovere A, Antonioli F and Bianchi CN (2015) Fixed biological indicators. In: Shennan I, Long AJ and Horton BP (eds) Handbook of Sea-Level Research. Hoboken, NJ: Wiley, pp. 268-280.

Rovere A, Raymo ME, Vacchi M et al. (2016) The analysis of Last Interglacial (MIS 5e) relative sea-level indicators: Reconstructing sea-level in a warmer world. Earth-Science Reviews 159: 404-427.

Rutter N, Radtke U and Schnack EJ (1990) Comparison of ESR and amino acid data in correlating and dating Quaternary shorelines along the Patagonian Coast, Argentina. Journal of Coastal Research 6: 391-411.
Rutter N, Schnack EJ, del Rio J et al. (1989) Correlation and dating of Quaternary littoral zones along the Patagonian coast, Argentina. Quaternary Science Reviews 8: 213-234.

Schellmann G and Radtke U (2000) ESR dating stratigraphically well-constrained marine terraces along the Patagonian Atlantic coast (Argentina). Quaternary International 68-71: 261-273.

Schellmann G and Radtke U (2003) Coastal terraces and Holocene sea-level changes along the Patagonian Atlantic coast. Journal of Coastal Research 19: 963-996.

Schellmann G and Radtke U (2010) Timing and magnitude of Holocene sea-level changes along the middle and south Patagonian Atlantic coast derived from beach ridge systems, littoral terraces and valley-mouth terraces. Earth-Science Reviews 103: 1-30.

Shennan I and Horton BP (2002) Holocene land- and sea-level changes in Great Britain. Journal of Quaternary Science 17: 511-526.

Shennan I, Long AJ and Horton BP (2015) Handbook of SeaLevel Research. Hoboken, NJ: John Wiley \& Sons, 634 pp.

Tamura T (2012) Beaches ridges and prograded beach deposits as paleoenvironmental records. Earth-Science Reviews 114: 279-297.

Tanner WF (1995) Origin of beach ridges and swales. Marine Geology 129: 149-161.

Terrasi F, De Cesare N, D'Onofrio A et al. (2008) High precision ${ }^{14} \mathrm{C}$ AMS at CIRCE. Nuclear Instruments and Methods in Physics Research 266: 2221-2224.

Terrasi F, Rogalla D, De Cesare N et al. (2007) A new AMS facility in Caserta/Italy. Nuclear Instruments and Methods in Physics Research Section B: Beam Interactions with Materials and Atoms 259: 14-17.

Vacchi M, Marriner N, Morhange C et al. (2016) Multiproxy assessment of Holocene relative sea-level changes in the western Mediterranean: Sea-level variability and improvements in the definition of the isostatic signal. Earth-Science Reviews 155: 172-197.

Walker SE, Parsons-Hubbard K, Richardson-White S et al. (2011) Alpha and beta diversity of encrusting foraminifera that recruit to long-term experiments along a carbonate platformto-slope gradient: Paleoecological and paleoenvironmental implications. Palaeogeography, Palaeoclimatology, Palaeoecology 312: 305-324.

Zanchetta G, Bini M, Isola I et al. (2014) Middle-to late-Holocene relative sea-level changes at Puerto Deseado (Patagonia, Argentina). The Holocene 24: 307-317.

Zanchetta G, Consoloni I, Isola I et al. (2012) New insights on the Holocene marine transgression in the Bahia Camarones (Chubut, Argentina). Italian Journal of Geosciences 131: 19-31. 